\title{
Constructing and Deconstructing
}

\section{the 'State': the Case of the Low}

\section{Countries}

FREDERIK BUYLAERT AND MARIE-GABRIELLE VERBERGT

The birth of the Low Countries is a thorny issue since the rise of history as an academic discipline in the nineteenth century, and the problem is likely to haunt historians for some time to come. From the eleventh century onwards, the patchwork of principalities that had emerged between France and the German Empire acquired a distinct cachet as most of these principalities became exceptionally urbanized. As Flanders, Brabant, Guelders, Holland, and so on were all fiercely independent, scholars all agree that the increasingly structural socio-economic integration of these urbanised regions did not automatically lead to political integration, even if the ruling dynasties of these principalities were prone to intermarry. Yet, this political integration did take shape in the fifteenth and early sixteenth centuries when a series of contingent factors - ranging from bankrupt princes to accidental deaths allowed a collateral branch of the royal house of Valois to inherit, to purchase, or to conquer a lengthy string of principalities that eventually stretched from Frisia to the Franche-Comté.

This development leaves historians with the challenge to ponder the nature of the dominions of the Dukes of Burgundy (1384-1477) and their Habsburg successors (1477-1567). The concept of 'the state' looms large in this discussion. As the southbound principalities of the Burgundian Valois (the duchy and county of Burgundy, Nevers, Picardy, and so on) were gradually reintegrated in the kingdom of France, the remaining northbound principalities became the substrate for the Dutch Republic and the Spanish-Austrian Netherlands, which in turn morphed into Belgium, The 
Netherlands, and Luxemburg. As the roots of these three present-day states are clearly situated with the clustering of principalities under Burgundian rule, the history of the Burgundian dominions is usually discussed in terms of the 'rise of the state', even if historians do not agree whether this Burgundian state was essentially 'medieval' or 'modern' in nature. Yet, as Timothy Reuter famously put it, 'it is only because rulers [...] seem to have been the drops around which the rain clouds of the modern states could form that they have been so readily invested with its qualities,' and some historians now wonder whether this statist perspective on fourteenth-, fifteenth-, and sixteenthcentury polities hides more than it reveals.

The question whether the aggregate of Burgundian principalities was a raindrop or a cloud has become more poignant than ever with two recent monographs that present diametrically opposed interpretations of the issue, namely Robert Stein's De Hertog en zijn Staten. De eenwording van de Bourgondische Nederlanden (2014) and Élodie Lecuppre-Desjardin's Le royaume inachevé des ducs de Bourgogne (2016). The first book builds on a long-standing tradition in that it argues that the Burgundian polity was a composite monarchy, that is, a loosely associated federation of states. The second book is the first concerted effort to avoid the concepts of 'state' and 'state-building' altogether: the author prefers to speak of 'the Great Seigniory of Burgundy' ('la Grande Principauté de Bourgogne'), a concept that already provoked scepsis in what is otherwise a highly favorable review of the book. ${ }^{2}$

The editors of BMGN - Low Countries Historical Review have invited Robert Stein and Élodie Lecuppre-Desjardin to review each other's books, as this discussion helps to identify both the common ground and the key points of contention in the debate on the earliest phase of Netherlandish history. As an introduction to these two reviews we must point out that in some respects, the two books proceed from different perspectives on what constitutes a 'state'. This is best illustrated by returning to the influential definition of the rise of the state by the American medievalist Joseph Strayer as

\section{... the appearance of political units persisting in time and fixed in space, the development of permanent, impersonal institutions, agreement on the need for authority which can give final judgements, and acceptance of the idea that this authority should receive the basic loyalty of its subjects. ${ }^{3}$} Empire and its Rulers in the High Middle Ages', in:

A.J. Duggan (ed.), Kings and Kingship in Medieval Europe (London 1993) 210.

2 See the review of Jan Dumolyn in American Historical Review (we are indebted to the author for a preview).
3 J. Strayer, On the Medieval Origins of the Modern State (Princeton 2005 [reprint of the first edition of 1970]) 10. 
Briefly put, Stein is attentive to the institutional criteria, whereas LecuppreDesjardin takes the issue of loyalty as the touchstone to discuss the absence of presence of a 'state' in the Burgundian realm. While the institutional perspective is the one that dominates much, if not all, of earlier scholarship on the Burgundian Netherlands, the perspective that probes for ideological support is equally valid. Little wonder, then, that the mutual reviews are respectful as both Stein and Lecuppre-Desjardin recognise that they have applied different lenses to the same problem. ${ }^{4}$

Also, both authors have two elements in common. First, Stein and Lecuppre-Desjardin both focus on the events between ca. 1380 and ca. 1480 . This is a surprisingly conventional time frame in a historiographical field that is strikingly inconsistent in its chronological focus: the death of Charles the Bold (1477), which precipitated the Habsburg succession, has been challenged long ago as a meaningful caesura for analysis by scholars who carry the question about the 'Netherlandish State' well into the 1500s, often up to the Dutch Revolt that started in 1567 . Second, both scholars are united in their disagreement with older views in which the Dukes of Burgundy often appear as preternaturally gifted 'statesmen' who were consciously building the foundations of modern polities. Even if Stein sees states where LecuppreDesjardin does not, he is inclined to understand them as the unanticipated result of actions that had different aims than bringing about 'the rise of the state'.

Yet, if the different definitions of Stein and Lecuppre-Desjardin have engendered books that are in many ways complementary rather than conflicting, these different approaches yield a striking set of contrasts that help to set the agenda for future research.

Firstly, historians need to address head-on the implications of their preferred geographical perspective. Just as many scholars before him, Robert Stein focused on those principalities within the Burgundian dominion that later became the core of the Northern and Southern Low Countries, ignoring those principalities that eventually became French. This self-imposed anachronism is consistent with the main argument of the book, in that Stein argues that the Burgundian polity as a whole was not so much a state, but a confederation of states, within which different clusters of states had different evolutions and, eventually, different destinies. Yet, this perspective also ties in with Stein's interpretation of institutional development, as Stein is inclined to give precedence to the internal logic of institutionalisation 
and bureaucratisation within Netherlandish institutions over an older, alternative interpretation in which the Burgundian Valois adopted French models of government to rule over the Low Countries. All this finds its perfect foil in the interpretation of Élodie Lecuppre-Desjardin. Proceeding from the well-established insight that the ideological and cultural framework of the Burgundian Dukes was essentially French, she develops the thesis that this framework was a real impediment for the Burgundian polity to become a state, as both rulers and subjects were preconditioned to imagine this dominium as an incomplete kingdom that did not have the 'persistence in time' nor the 'fixity in space' that are central to Strayer's criteria to identify emerging states. A first question for follow-up research on the history of institutions in Flanders, Brabant, Frisia, and so on, is thus whether questions about loyalty and identification (the criterion favored by Lecuppre-Desjardin) are relevant or not to questions about institutional development (the criterion favored by Stein). Answering this question will reveal whether the myopia that comes with a focus on the 'Netherlandish' segment of the Burgundian realm fatally distorts any political analysis of late medieval polities in this corner of Western Europe or not.

Secondly, historians will have to revisit the 'feudal' or 'modern' character of late medieval Netherlandish-Burgundian societies. Proceeding from the same spate of studies on rural elites and court elites, Stein and Lecuppre-Desjardin develop conflicting interpretations. One of the main reasons that Stein sees sufficient grounds to speak of 'rising states' in the fifteenth century is that he sees a radical social transformation in which 'stuffy' feudal elites lose out to a bourgeois milieu of merchants and bureaucrats (see especially $266,274-275)$. In contrast, Lecuppre-Desjardin sees a society that is so decidedly 'feudal' - i.e. polyarchic - that the state as an institution that at least aspired to a monopoly on the use of force was quite unthinkable (see especially chapter 2 and 350-351).

This structural dissent about the social basis of politics also includes urban communities. Urban historiography has expanded massively for the Netherlandish parts of the Burgundian polity in the past decades, but again, this body of scholarship leads to incompatible interpretations in the hands of two different scholars. Stein, proceeding from his claim that urban commercial milieus reaped great benefits from the rise of the Burgundian Dukes, sees no deficit in 'basic loyalty' as a criterion in Strayer's definition: in a move that is already contested, the frequent revolts in Netherlandish towns are reduced to mere hiccups in the structural social collaboration between the Dukes and his urban subjects (see especially chapter 3 and 269, 275). ${ }^{5}$ Lecuppre-Desjardin has carried the available evidence in a very different 
direction: for her, these revolts betray a deep-rooted incompatibility between the political ideology of the Burgundian princes and that of their subjects (see especially 136-138).

Both scholars have done a great service to anyone who is interested in the 'Burgundian' phase of Netherlandish history: their interpretations, each articulated with great care and clarity, help to define the problems that need to be addressed. Above all, their books and mutual reviews reveal that the challenge of re-imagining or discarding 'the state' in Netherlandish historiography is not the esoteric problem of specialists in institutional history, but a project that brings together cultural, economic, social, and political historians in the twenty-first century.

Frederik Buylaert (1981) is research professor of late medieval and early modern history at the University of Ghent. His research focuses on social history, urban history and the history of state formation. Recent publications include: 'Record Keeping and Status Performance in the Early Modern Low Countries', Past \& Present 230 (Supplement 11: L. Corens, K. Peters and A. Walsham (eds.) The Social History of the Archive: RecordKeeping in Early Modern Europe) (2016) 131-350; (with J. Haemers); 'Lordship, Urbanisation and Social Change in Late Medieval Flanders', Past \& Present 227 (2015) 31-75; 'The Transformation of Rural Elites in Late Medieval Flanders. Oligarchy, State Formation and Social Change in the Liberty of Bruges (ca. 1350-ca. 1525)', Continuity \& Change 30 (2015) 39-69 (with A. Ramandt). Email: frederik.buylaert@ugent.be.

Marie-Gabrielle Verbergt MA (1995) is a historian and Master's student in the Social Sciences (The University of Chicago) with an interest in theoretical history, twentiethcentury historiography and medieval history. Recent work: Mediëvisten en moderniteit. Periodisering in het debat over de 'Bourgondische staat' na 1945 (Master's thesis Ghent University 2017).Email: mariegabriellev@uchicago.edu. 